\title{
Some Aspects of Digitalization Processes in Education
}

\author{
Nugumanova L.N.", Shaukhutdinova G.A., Jakovenko T.V. \\ Institute of Education Development of the Republic of Tatarstan, Kazan, Russia \\ ${ }^{*}$ Corresponding author. Email: lyudmila.nugumanova@tatar.ru
}

\begin{abstract}
The authors of the article consider the possibilities of digital education, which today carries a huge potential for learning. Opportunities for personalized learning are emerging, new models of cooperation are emerging, and the range of innovative and attractive learning strategies for students is becoming wider.

When immersed in the digital space, a child has a whole series of new expectations and interests, motives and goals, needs and attitudes, as well as forms of psychological and social activity that are directly related to the new life field of digital interaction. The virtual environment carries a huge educational, developmental potential. At the same time, the authors believe that educational, personality-forming influences that can be of the most varied and sometimes unpredictable nature should not be overlooked. The process of the digital transformation of education directly depends on how much the teachers themselves are involved in the "digital", what is their personal innovative potential: attitudes towards technologies, practices of their use and the level of digital subjectivity (agency).
\end{abstract}

Keywords: digitalization of education, teacher, student, digital environment, digital technology

\section{INTRODUCTION}

The education system is at the center of all the innovations taking place in the social and economic spheres, therefore the progressive development of modern Russia and its regions, including the Republic of Tatarstan, directly depends on the effectiveness of digitalization processes in the field of education. In these conditions, one of the most important tasks of the Institute for the Development of Education of the Republic of Tatarstan is the promotion of digital technologies in the education system.

The purpose of the article is to identify the productive strategies for integrating the education of the Republic of Tatarstan into the global innovation process, as well as to identify the innovations that occur in improving the pedagogical skills of teachers, with the advent of digitalization. The authors consider it extremely relevant to establish which technologies currently define digital transformation and made an attempt to answer these questions in their publication.

\section{METHODOLOGY}

The study was conducted on the basis of the analysis of international and Russian experience in the digitalization of education, as well as in the framework of informational, competency-based approaches. The information

approach operates with concepts such as "information" and "knowledge". Obviously, due to the availability and convenience of extracting information from the Internet, digital sources are increasingly replacing the traditional transfer of knowledge and traditional storage media. The need for an information campaign in education is determined not only by the fact that the Internet and digital media are a source of knowledge, but that this knowledge will become personal only when it acquires meaning for the student. In this case, we need a competency-based approach that allows us to establish links between knowledge and the situation, to formulate the procedure for acquiring knowledge as a solution to the specific problem that is necessary for the student at the moment.

\section{RESEARCH RESULTS}

One of the first meanings of the term "digital transformation" is the transition from analog to digital data, which is commonly called digitalization today. An analysis of the data that is publicly available on the Internet shows that by 2020 the share of analog data will approach zero, that is, the digitalization process in the narrow sense of the word will end.

In a broad sense, the digitalization process continues, and for different specialists, it has various accents. It should also be noted that, speaking of digital transformation in relation to a country, city or individual organization, we will encounter different specifics of its interpretation. Let us consider several approaches. 
1. Technology-based digital transformation. Proponents of this approach believe that each period is characterized by its own digital transformation as a set of ICTs, which allows creating a certain qualitative leap.

2. Digital transformation as a transformation based on the third platform. Many researchers believe that digital transformation is a new trend, and connect it with a certain set of new technologies - this is the emergence of the "Third Platform" (clouds, mobility, social networks, "big data"). According to adherents of this point of view, for example, all previous technologies only prepared for digital transformation. Digitization was paving the way for future transformation.

\section{Digital transformation as a business} transformation. In a business environment, when they talk about "digital transformation", it is primarily about using the latest technology to do what you are already doing, but better! According to the definition of Microsoft, the main goal of digital transformation is to increase competitiveness and enable it to develop in an everchanging economic environment.

We examined the most common definitions of digital transformation, however, when it comes to a specific industry, the spectrum of transforming technologies and organizational measures is specified, as industry specifics are manifested. Let's move on to the education system.

Distance education and e-learning laid the foundation for a new global phenomenon - smart education. And this is not about technology, but about a new philosophy of education. ICTs have prepared the birth of a new world where there are practically no barriers to the creation, exchange, and dissemination of knowledge.

Today's schoolchildren and students are generation Z, or the "digital generation" (children born 1995-2012) - live in the phydgital world (from physics + digital), where there are no borders between real and virtual. Access to information (= internet) and peer contact for Generation $\mathrm{Z}$ are essential as air. They are always in touch and up to date with everything that happens on the planet. In the world of generation $\mathrm{Z}$, everything is personalized, so the selection of relevant knowledge on an individual trajectory is organic for them. Generation $Z$ is the do-it-yourself generation. It easily juggles virtual sources of information, instantly extracting the information needed here and now, fluently switches between tasks, enthusiastically tries new things. It likes gamification, 3D-models and virtual reality in the educational process. For these schoolchildren, it's natural that you can visit the Louvre without getting up from your desk, or, wearing VR glasses, see in volume the figure whose parameters they just calculated.

Signs of the digital generation

- $\quad$ Fixing attention on one subject no more than 8 seconds.

- Inability to understand and read large texts
- The mix of real and virtual

- The illusion of the reversibility of life

- Perception of real life as too boring and too slow

- Text perception speed is 120 words per minute

- Infantilism (the imbalance between advanced intelligence and lagging social and personal development)

- Individualism

- $\quad$ Confidence in its uniqueness

- $\quad$ Focus on the inner world

- $\quad$ The pursuit of personal freedom

- $\quad$ Avoiding standard models

- $\quad$ Reduced need for live communication

- The value of self-education is higher than the value of formal education

- Hyperpragmatism

Obviously, the need arose to create a new education system: digital or smart education. Smart has become the paradigm for the rapid development of the information society. This required a transition from the decades-old paradigm of "learning for all life" to the "lifelong learning" paradigm.

\section{DISCUSSING THE RESULTS OF RESEARCH}

The processes of informatization, multimedia, and virtualization as successful trends in the development of education have substantially changed the characteristics of not only the educational process itself but also the educational space. Therefore, there are practically no ways to update the continuing education of teachers without taking into account the features and innovations caused by the above processes.

The development of the digital educational environment of continuing education is a transformation of the educational process and its elements, on the one hand, and digital technologies, and the tools used in the educational process, on the other side.

The goal of the digital transformation of the educational process is to maximize the use of the capabilities of digital technologies aimed at improving the professional skills of teachers and corresponding to state priorities in this area, which are already enshrined in regulatory documents the stages of solving the tasks.

Let us consider some of the new technologies that are changing the landscape of education. 
1. Adaptive learning. Adaptive learning is an approach that maximally takes into account the individual abilities and needs of the student. The use of adaptive technologies involves the integration of information and pedagogical technologies that ensure interactivity between the participants in the educational process and the productivity of educational activities.

Examples of platforms that specialize in adaptive learning: Knewton (a service that takes into account everything in the learning process, even the mood of the student), McGraw Hill Education (provides individual educational content, software and other services, starting with preschool children and ending with postgraduate education).

2. Virtual reality technology (VR). Integrated technology that allows you to immerse a person in an immersive (providing the full effect of presence) virtual world using specialized devices (virtual reality helmets).

3. Technology of Augmented Reality (AR). A technology that allows you to integrate information with real-world objects in the form of text, computer graphics, audio and other representations in real time. Information is provided to the user using heads-updisplay (indicator on the windshield), glasses or helmets of augmented reality (HMD) or some other form of projecting graphics for a person (for example, a smartphone or projection video mapping). Augmented reality technology allows to expand user experience with the environment.

4. Blended learning. Blended learning is a technology for organizing the educational process, which is based on the concept of combining the technologies of the traditional class-lesson system and e-learning technologies, based on new didactic opportunities provided by ICT and other modern teaching tools.

The growing popularity of blended learning is due to the ability to increase the effectiveness of the educational process due to the optimal combination of the advantages provided by both traditional learning and distance learning technologies.

5. Gamification. Gamification is the use of game elements in a non-game context, that is, the process when game elements are used to achieve educational goals. It is important that gamification is not the creation of a fullfledged game, but only the use of certain elements. When an element of the game is introduced into the learning process, this allows the student to engage emotionally, and this almost immediately leads to a concentration of attention on the task, easier memorization and interest.

6. Artificial Intelligence (AI). Intelligence is the ability to perceive information and save it as knowledge to build adaptive behavior in an environment or context.

The presence of intelligence does not imply the presence of consciousness. This is a common misconception brought to the world by science fiction writers.

Artificial intelligence is a science whose main problems are the formalization of knowledge, experience, ingenuity, activity and the use of the results to solve intellectual problems and create knowledge-based systems.
Artificial intelligence is so tightly integrated into the technologies we use today that many people don't even think of it as "artificial intelligence", they do not separate it from ordinary computer technologies. Artificial intelligence is everywhere: from predicting the entered text to the automatic focus of the camera, speech recognition, text, face, image, audio, video information, etc.

The range of technology applications is constantly growing and includes unmanned vehicles, medical diagnostics, computer games, search engines, spam filters, crime control, marketing, robot control, computer vision, transportation, music recognition and much more. Many believe that artificial intelligence should appear in the future. But it appeared some time ago and is already here, next to us.

As part of the implementation of the National Strategy for Children, the Strategy for the Development of Education in the Russian Federation until 2025, the Concept of State Family Policy in the Russian Federation until 2025, the Fundamentals of the Strategy for State Youth Policy in the Russian Federation until 2025, the state program for patriotic education of citizens for 2016-2020, for the first time in their history, the educational component was included in state educational standards that contributed to the modernization of upbringing in the learning process, streamlining common requirements for its implementation. As part of the implementation of educational activities, as well as improving the forms and methods of educational work in educational organizations, the Institute implements a series of thematic webinars "Open Class". The project touches on topical issues of education and is aimed at class teachers, the parent community and other interested parties. Within the framework of this project, open distance learning courses for parents "Fundamentals of Child Psychology and Pedagogy" are being implemented.

Implementation of measures aimed at developing the professional skills of educators is impossible today without the involvement of partner organizations: leading educational organizations of the Russian Federation, publishers, and online educational platforms. Among them are organizations such as Kazan Federal University, Higher School of Economics, Russian Academy of Education, Federal Institute for Educational Development of the Russian Presidential Academy of National Economy and Public Administration, RUSNANO School League, Russian Word publishing houses and online platform, Fizikon, Library school, YaKlass, and many others.

\section{CONCLUSION}

Thus, the implementation of federal projects, educational and professional standards, educational technologies of Industry 4.0, all this requires a teacher considerable efforts for professional growth and, accordingly, determines the search for new approaches to additional professional teacher education in the context of digitalization. 
The key areas of professional development implemented within the framework of digitalization are new approaches to organizing the process of enhancing teaching skills: distance learning, webinars, the use of digital technologies and tools, teamwork.

Today, the Institute for the Development of Education is embedded in the unified digital environment of state Internet resources, which is called "GosWeb", is the regional operator of the digital environment portal for continuing professional education, and employees are federal experts of the portal; continuing professional education programs take part in a pilot project of the Department for the Development of Pedagogical Personnel and Resource Management Control of the Ministry of Education of Russia "Selection of the best electronic educational resources for organizing training in continuing education programs".

Implementation of continuous monitoring of professional inquiries and deficits of educators of the Republic of Tatarstan allows you to build individual educational trajectories of the teacher's professional development, forming groups and a variable part of the educational program, taking into account the elimination of identified professional deficits of educators.

The network interaction of partner organizations on the electronic platform allows you to accumulate the potential of educational organizations involved in the professional development of a teacher, to attract leading organizations and specialists in the field of education both in the Republic of Tatarstan and the Russian Federation.

The world is changing so quickly that we can no longer afford to study theoretical disciplines for five years, and then learn the profession for some time at the expense of the employer. Therefore, education is becoming more substantive, practice-oriented and digital learning is becoming necessary.

\section{REFERENCES}

[1] Anikina Ye.I. Perspektivy primeneniya mobil'nykh ustroystv dlya realizatsii tekhnologiy elektronnogo obucheniya v vysshem obrazovanii // Innovatsii v obrazovanii. - 2019. - No. 6. - S.83-91.

[2] Blinov V.I. Tsifrovaya didaktika: modnyy trend ili novaya nauka? // Professional'noye obrazovaniye. Stolitsa. - 2019. - No. 3. - S.27-33.

[3] V Rossii formiruyetsya sovremennaya tsifrovaya obrazovatel'naya sreda // Professional'noye obrazovaniye. Stolitsa. - 2019. - No. 3. - S.39-41.

[4] Ganeyev A.R. Tsifrovaya shkola: ya uchus' ili menya uchat? / A.R. Ganeyev, V.A. Vlasenko // Standarty i monitoring v obrazovanii. - 2019. - No. 1. S. 36-41.
[5] Denisov I.V. Studenty setevogo pokoleniya: lateral'nyye profili i tsifrovyye navyki // Informatika $\mathrm{i}$ obrazovaniye. - 2019. - No. 2. - S. 34-41.

[6] Markina I. Tsifrovizatsiya v obrazovanii: pochemu yeye ne stoit boyat'sya // Professional'noye obrazovaniye. - 2019. - No. 8. - S. 45-46.

[7] Nikonov V. "Tsifrovizatsiya menyayet obrazovatel'nuyu i professional'nuyu sredu, sozdavaya novyye potrebnosti na rynke truda" // Professional'noye obrazovaniye. - 2019. - No. 1. - S. 49-50.

[8] O proyekte "Rossiyskaya elektronnaya shkola". Pis'mo Minprosveshcheniya Rossii ot 20.02.2019 No.03-238 // Administrator obrazovaniya. - 2019. No. 7. - S. 16.

[9] Obrazovaniye na perekhodnom etape. Ot klassicheskogo - $\mathrm{k}$ tsifrovomu // Professional'noye obrazovaniye. - 2019. - No. 2. - S.15.

[10] Programma SELFIE dlya tsifrovogo obrazovaniya v shkolakh Yevropy // Professional'noye obrazovaniye. - 2019. - No. 2. - S. 51.

[11] Robert I.V. Didaktika epokhi tsifrovykh informatsionnykh tekhnologiy // Professional'noye obrazovaniye. Stolitsa. - 2019. - No. 3. - S.16-27.

[12] Sovremennaya tsifrovaya obrazovatel'naya sreda: parusa informatsionnogo okeana // Professional'noye obrazovaniye. Stolitsa. - 2019. - No. 4. - S.49-51.

[13] Uvarov A.YU. Ot komp'yuterizatsii do tsifrovoy transformatsii obrazovaniya // Informatika i obrazovaniye. - 2019. - No. 4. - S.5-12.

[14] Fenomena "Pokoleniya Z" ne sushchestvuyet, oni prosto podrostki, zhivushchiye $\mathrm{V}$ novoy srede // Professional'noye obrazovaniye. Stolitsa. Prilozheniye. - 2019. - No. 4. - S.32-34.

[15] Tsifrovaya adaptatsiya. Kak pedagogam uchit' tekh, kto rozhden $\mathrm{V}$ tsifrovuyu epokhu // Professional'noye obrazovaniye. - 2019. - No. 7. S.49-50.

[16] Tsifrovizatsiya - strategicheskaya tema formirovaniya sovremennogo obrazovatel'nogo protsessa // Professional'noye obrazovaniye. - 2019. No. 7. - S.3-12. 